\title{
Teaching Video Neuroimages: Spontaneous Nystagmus Reversal in Acute Attack of Ménière Disease
}

Anand K. Bery, MD, and Tzu-Pu Chang, MD

Neurology ${ }^{\circledR}$ 2021;96:e2145-e2146. doi:10.1212/WNL.0000000000011053

Figure Differentiating the Nystagmus Reversal in Acute Ménière Disease From Periodic Alternating Nystagmus

Nystagmus in acute Ménière disease (case)

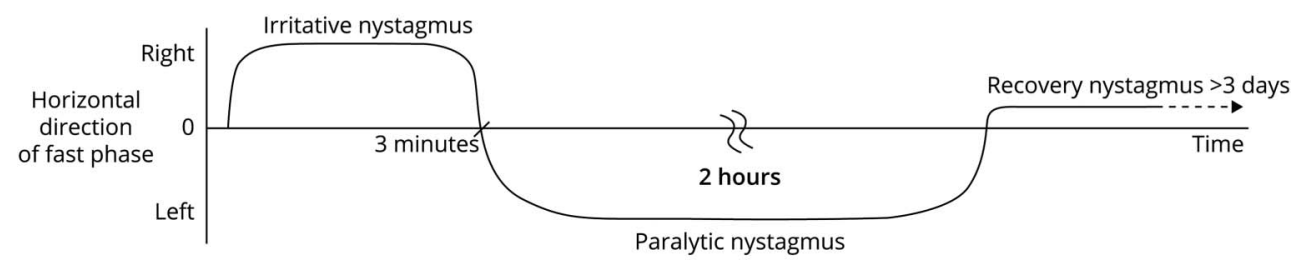

Periodic alternating nystagmus

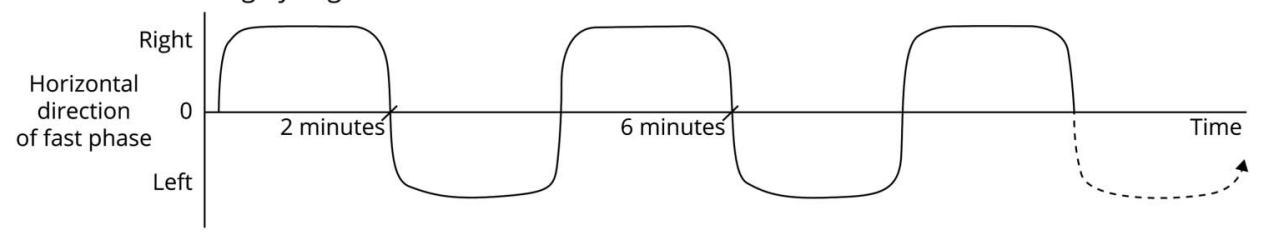

Nystagmus in acute Ménière disease (top trace) initially beats towards the affected ear. Over minutes, it changes direction. In some patients, there is one more direction change and a recovery nystagmus. By contrast, periodic alternating nystagmus (bottom trace) alternates direction (through a null point) indefinitely with a fixed period of 1 or 2 minutes. Traces are illustrative only.

A 65-year-old woman with right-sided Ménière disease experienced one of her usual and frequent acute vertigo attacks during eye movement recording (video 1). The attacks were associated with right-sided tinnitus, hearing loss, and vomiting. She initially demonstrated rightbeating nystagmus, but after 2 minutes, the nystagmus gradually reversed and became leftbeating (video 1). During the reversal, downbeat nystagmus was present temporarily. The leftbeating nystagmus then persisted for 2 hours.

We captured the classic change in direction of spontaneous nystagmus in acute Ménière disease (figure). ${ }^{1}$ Our patient demonstrated initial irritative nystagmus beating towards the affected ear, followed by paralytic nystagmus beating towards the unaffected ear. ${ }^{1}$ The temporary downbeat nystagmus suggests vertical canal involvement. Although downbeat nystagmus usually indicates a cerebellar lesion, our case supports the existence of peripheral downbeat nystagmus, caused by either stimulation of the anterior canal or inhibition of the posterior canal. ${ }^{2}$
Correspondence

Dr. Chang

neurochang0617

@gmail.com

\section{MORE ONLINE}

- Video

$\rightarrow$ Teaching slides

links.lww.com/WNL/

B257

From the Division of Neurology (A.K.B.), Department of Medicine, University of Ottawa, Ontario, Canada; Department of Neurology/Neuro-medical Scientific Center (T.-P.C.), Taichung Tzu Chi Hospital, Buddhist Tzu Chi Medical Foundation; and Department of Neurology (T.-P.C.), School of Medicine, Tzu Chi University, Hualien, Taiwan.

Go to Neurology.org/N for full disclosures. Funding information and disclosures deemed relevant by the authors, if any, are provided at the end of the article. 


\section{Study Funding}

No targeted funding reported.

\section{Disclosure}

The authors report no disclosures relevant to the manuscript. Go to Neurology.org/N for full disclosures.

\section{Appendix Authors}

\begin{tabular}{lll}
\hline Name & Location & Contribution \\
\hline $\begin{array}{l}\text { Anand K. } \\
\text { Bery, MD }\end{array}$ & $\begin{array}{l}\text { Division of Neurology, Department } \\
\text { of Medicine, University of Ottawa, } \\
\text { Ontario, Canada }\end{array}$ & $\begin{array}{l}\text { Drafting the paper } \\
\text { and the video legend; } \\
\text { creating the figure }\end{array}$ \\
\hline
\end{tabular}

Appendix (continued)

\begin{tabular}{lll}
\hline Name & Location & Contribution \\
\hline Tzu-Pu & $\begin{array}{l}\text { Department of Neurology/Neuro- } \\
\text { Chang, }\end{array}$ & $\begin{array}{l}\text { Recording the video and } \\
\text { medical Scientific Center, Taichung }\end{array}$ \\
MD & $\begin{array}{l}\text { Tzu Chi Hospital, Buddhist Tzu Chi } \\
\text { Medical Foundation, Taichung; }\end{array}$ & \\
& $\begin{array}{l}\text { Department of Neurology, School } \\
\text { of Medicine, Tzu Chi University, }\end{array}$ & \\
& Hualien, Taiwan & \\
\hline
\end{tabular}

\section{References}

1. Bance M, Mai M, Tomlinson D, Rutka J. The changing direction of nystagmus in acute Meniere's disease: pathophysiological implications. Laryngoscope 1991;101: 197-201.

2. Lee SU, Kim HJ, Lee ES, Choi JY, Kim JS. Ictal downbeat nystagmus in bilateral Meniere's disease. J Neurol 2017;264:2024-2026. 


\section{Neurology}

\section{Teaching Video Neuroimages: Spontaneous Nystagmus Reversal in Acute Attack of Ménière Disease}

Anand K. Bery and Tzu-Pu Chang

Neurology 2021;96;e2145-e2146 Published Online before print October 14, 2020

DOI 10.1212/WNL.0000000000011053

This information is current as of October 14, 2020

\section{Updated Information \&} Services

\section{References}

Subspecialty Collections

Permissions \& Licensing

Reprints including high resolution figures, can be found at: http://n.neurology.org/content/96/16/e2145.full

This article cites 2 articles, 0 of which you can access for free at: http://n.neurology.org/content/96/16/e2145.full\#ref-list-1

This article, along with others on similar topics, appears in the following collection(s):

All Neurotology

http://n.neurology.org/cgi/collection/all_neurotology

Nystagmus

http://n.neurology.org/cgi/collection/nystagmus

Vertigo

http://n.neurology.org/cgi/collection/vertigo

Information about reproducing this article in parts (figures,tables) or in its entirety can be found online at:

http://www.neurology.org/about/about_the_journal\#permissions

Information about ordering reprints can be found online:

http://n.neurology.org/subscribers/advertise

Neurology ${ }^{\circledR}$ is the official journal of the American Academy of Neurology. Published continuously since 1951, it is now a weekly with 48 issues per year. Copyright @ 2020 American Academy of Neurology. All rights reserved. Print ISSN: 0028-3878. Online ISSN: 1526-632X.

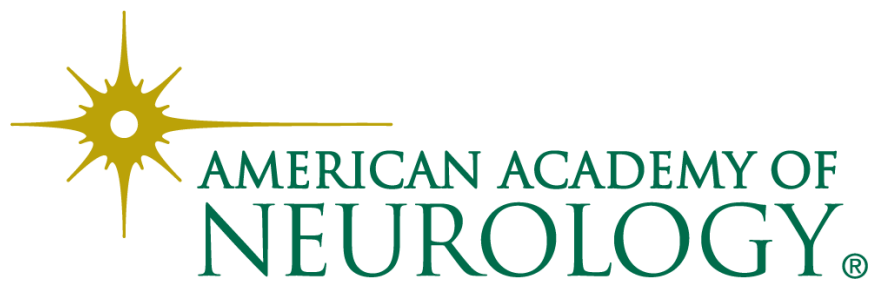

